\title{
Cascading corruption news: explaining the bias of media attention to Brazil's political scandals
}

Mads Damgaard

\section{Introduction}

Since 2014, a mudslide of corruption allegations and scandals has caught the attention of Brazilian media with the corruption probe code-named Lava Jato (Operation Car Wash), but remarkably few politicians suffered the consequences of being involved in corruption in the state company Petrobras. In the first half of 2016, the mainstream media disregarded many elements of the ongoing scandal, choosing instead to cover the impeachment proceedings against President Dilma Rousseff intensely. Rousseff and the other leader of the Workers' Party (PT), her mentor Luiz Inácio Lula da Silva, were both under public scrutiny for commanding the corruption scheme in the state oil company Petrobras, and other government coalition parties, most notably the PMDB and PP, were also investigated in the Lava Jato case. However, the investigations that documented the coalition partner parties' graft and bribe-taking gradually vanished from the limelight of the media while the impeachment process gained momentum; paradoxically in the very same period that these parties prepared to grab the reins of the Presidency.

Why was news on the corruption of these political actors so underexposed in the mainstream Brazilian media, and how could the media fail to hold the politicians coming into power accountable? Answering these questions exposes information processes in the mediatized public sphere of Brazil that are detrimental to both democracy and the combat against corruption.

This article explores the coverage of corruption and impeachment in the mainstream media of Brazil, through a content analysis of Folha de S. Paulo, O Estado de S. Paulo, and $O$ Globo in the sample period of the six months leading up to the impeachment of Dilma Rousseff. In this period, more than a hundred different political corruption cases were the topic of news items, but only a select few received sustained coverage. Based on the findings of this content analysis of the national newspapers, I study the recycling of particular signals of political transgression and corruption as a kind of information cascade. Finally, I discuss how these signals, amplified by the media's overexposure and simultaneous disregard for other corruption cases, could be interpreted as a deliberate intra-elite strategy (Peruzzotti, 2006; Balán, 2011) aiming to eclipse questions of political accountability.

Information cascades may tempt individuals-voters as well as decisionmakersto make their choices based on the public sequence of information rather than the quality 
of this information. Such sequences might influence the choices of an electorate or a group of decision-makers a great deal. Snowballing media phenomena similar to cascades have been theorized from various perspectives and under various names: scandals, media storms, moral panics, and media hypes are separate concepts scattered in media studies, although they have a lot in common (Boydstun, 2013; Thompson, 2000; Tumber and Waisbord, 2004; Welch, Price and Ynakey, 2002; Wien and Elmelund-Præstekær, 2009). These disparate concepts all have theoretical affinities with the general media theory called agenda-setting (McCombs and Shaw, 1972; McCombs, 2009), but conceptualizing such media phenomena in a broader social context has only recently been attempted through the notion of information cascades (Hansen, Hendricks and Rendsvig, 2013; Hendricks and Hansen, 2014).

The consequences of a cascade of information can explain bias of overall media attention, such as the anti-government bias documented in Brazilian media (Feres Júnior and Sassara 2016a, 2016b; Lima, 2006), but investigating cascades goes beyond that: by using this conceptualization, rather than ad hoc theories defined by characteristics specific to certain media topics, media theory gains a valuable tool in grasping the general social mechanisms involved in the chain reactions of media, public actors, and public opinion. These dynamic mechanisms might drive public opinion and policymaker attention (Boydstun, 2013), but also create pluralistic ignorance of the true state of events (Wiewiura and Hendricks, 2017).

\section{The concept of cascades}

Informational cascades form the basis of what has been termed infostorms. Hendricks and Hansen (2014 following Bikhchandani, Hirshleifer and Welch, 1998) point out how informational cascades might be harmful to democratic societies, when decisionmaking is based on social proof gleaned from publicly available signals rather than verified knowledge. The social proof of massive media coverage, polls, and street protests, however, does not amount to true information about the state of politics.

Conceptually, informational cascades consist in rationally acting actors, sequentially passing along information through their public actions. The actors cannot derive private knowledge possessed by other actors, but nonetheless, all observing actors take the actions to be significant down the sequence stream. When making their respective choices, these actors might then base their actions on false assumptions about the private knowledge of others, adding to the weight of the social proof. Cascades emerge when all actors make the same assumptions, reproduce the action, and pass on the same signaleven when the signal might be untrue. This mechanism might occur both in physically copresent publics, in online publics, or even between collective actors such as media organizations.

In this article, the cascade mechanism emerging from the media's coverage of the 
Lava Jato scandal is under scrutiny. In the context of media, the mechanism consists in disclosed information about corruption, reaching the public via news agencies, front pages, political news media, or news broadcasts. When various media outlets repeat the same signal over and over, an information cascade might form. The cascade is anchored in the practical task of the individual journalist, who, in order "to flesh out any one supposed fact (...) amasses a host of supposed facts that, when taken together, present themselves as both individually and collectively self-validating" (Tuchman, 1978, p. 86). Thus, in the everyday practice of making sense of events and transforming them into news, journalists reproduce a certain truth regime (Foucault, 1980). A hegemonic interpretation of national politics, for example, could be reproduced over and over again by journalists, because this will present the shortest route to validate and interpret new information culled from sources. Shoemaker and Vos (2009, p. 52) observed that editors and other gatekeepers of news will also be prone to groupthink and generally assess the importance of news in the same way across the board of a media system. The self-validation is repeated at the institutional level, where

[m]edia institutional actors rely extensively on each other not only as sources of reference but also as sources of institutionalized legitimacy, even though they lack first-hand access to the event. This reflects the general tendency in contemporary journalism of including the perspectives of media institutions, commentators, correspondents and other media professionals in the news coverage as opposed to involving sources outside the media institutional realm (Kristensen and Mortensen, 2015, p. 360).

Thus, when media professionals and media outlets rely on other outlets and professionals for information, news priorities, and mutually legitimating truth regimes, a feedback-loop emerges that reproduces the same signal many times over. This might then build up into a cascade. The cascade only triggers when there is "a preponderance of evidence [that] supports one action or the other by just enough to outweigh one individual's private signal" (Bikhchandani, Hirshleifer and Welch, 1998). Once an actor decides to act upon that information, this constitutes another piece of evidence for others to see, as his or her action is also a signal. A cascade of signals might build up into a political scandal between journalists, editors, and newsrooms mimicking each other through pack journalism, producing explosive amounts of coverage (Boydstun, 2013, p. 47; Walgrave and Vliegenthart, 2010), as described above. This is then repeated in communication amongst audience members: in corruption scandals, when more and more people start to call for the resignation of a given politician, that call seems to be justified for an increasing number of people, and joining the bandwagon, this call for action reinforces itself, resulting in a feedback-loop (Hendricks and Hansen, 2014, p. 91ff).

To empirically detect an information cascade, the research design needs to account 
for the signals of the media in some form of content analysis ${ }^{1}$. Content analysis is also traditionally used for agenda-setting research designs. Agenda-setting theory originally identified the relation between media coverage and the media audiences' perception of salience of issues (McCombs, 2009), and it is theoretically possible to predict the immediate result of a cascade between media actors using agenda-setting theory: An information cascade in the media would likely produce an agenda-setting effect, and an agenda-setting research design could thus be used to analyze the skewed salience transfer effect of a information cascade in media - potentially in the form of explosive surges of coverage, common to scandals. The Lava Jato scandal's salience transfer effects has already been studied from this angle: Baptista has demonstrated that during the Lava Jato scandal, the approval ratings of the Rousseff administration and trust in federal government were significantly correlated to the media coverage of scandals (Baptista, 2017). As predicted by agenda-setting theory, the extensive coverage made problems of governmental corruption very salient to a Brazilian audience already tuned in to the anticorruption agenda.

The agenda-setting effect of a cascade is not surprising; neither is it surprising that the media emphasized the impeachment proceedings in their coverage of the political crisis. It is urgent to ask, however, what caused or motivated the lack of attention to other corruption cases, especially those that implicated political parties and decision-makers coming into power. In other words, how did the crisis lead to Rousseff's downfall, rather than that of all the government parties? The well-known salience transfer effect of scandals (which translates into lower political support and regime legitimacy, e.g. Maier, 2011; Seligson, 2002) is not as interesting as the de-selection of information that gradually emerged along with the cascade: how could the very active media disregard some parts of the Lava Jato scandal while reproducing the signal of crisis and calling for the ousting of the President Rousseff, only to put a corrupt Vice President in her place? Before tackling this question, I will present the research design and sampling strategy.

\section{Operationalization and sampling strategy}

In the following, I undertake a content analysis of the news items that deal with corruption. The content analysis does not compare the amount of news on corruption to news dealing with other topics, but examines the distribution of news items reporting or commenting on the plethora of corruption cases in the Brazilian political system. The goal

\footnotetext{
1 Other researchers have addressed similar phenomena with the same approach: Boydstun (2013, p. 82) (constructing a study around the term "media storm" and patterns of media attention) sampled news items of front pages and coded the news items for issues. Russell and Waisbord (2017), analyzing so-called "news flashpoints", or bursts of coverage, likewise analyzed frequencies of news items (but only items related to the Snowden leaks). Both studies dealt with the New York Times, and both worked with a content analysis methodology (Russell and Waisbord, 2017, p. 860). Brazilian researchers such as Feres Júnior and Sassara (2016b) and Baptista (2017) have also recently used variations of content analysis in comparable research designs.
} 
is, first, to map out the dynamic evolution of media attention devoted to national political scandals. Second, this content analysis might detect feedback patterns in the coverage of particular cases, where coverage heaps up, drawing away resources and attention to other cases.

Earlier studies of Brazilian media scandals have examined the prestigious newspapers that feed information to a range of associated media outlets (e.g. Feres Júnior and Sassara, 2016a; Biroli and Mantovani, 2014; Miguel and Coutinho, 2007). The Brazilian media system is concentrated into a few conglomerates (Biroli and Miguel, 2013; Cabral, 2015; Matos, 2012), and despite new entrepreneur journalists and grass-roots news platforms (such as MidiaNINJA, JornalGGN, Tijolaço, and O Antagonista), there is a high level of vertical integration in the production on national political news: To a large degree, the regional and metropolitan newspapers and broadcasts get their national political news mainly from the newsrooms and agencies of three conglomerates-either the two São Paulo-based newspapers Folha de S. Paulo and O Estado de S. Paulo, or the network of Globo news media (the newspaper $O$ Globo, the newscasts Jornal Nacional and GloboNews, the website G1, and the weekly magazine Época). Abramo found that the news recycling is determined by the media organization structure:

Not only the penetration of [Rio- and São Paulo-based] newspapers is much higher than the press from other regions, but they also tend to dominate what the other newspapers publish. Upon analyzing the credited sources of stories published by the newspapers (about $14 \%$ of stories are credited to news agencies), it is found that the news agencies associated with two newspapers (Folha and Estado) are responsible for $90 \%$ of all agency-credited news published by the newspapers (...) Adding the Globo agency, the percentage is $95 \%$. This does not count news items that are simply appropriated by a newspaper without credit, a very common phenomenon (Abramo, 2007, p. 99).

Therefore, in order to detect the frequency of coverage of different corruption cases and the impeachment process, three central media outlets are sampled here as a proxy for the entire mediascape ${ }^{2}$. Although the printed versions of Brazilian newspapers do not reach large shares of the population, relative to other countries (Albuquerque, 2011, p. 78; Lattman-Weltman and Chagas, 2016, p. 337), their newsrooms are usually first to report on disclosure of corruption, and they are thus the first potential instances in an information cascade. News from Folha, Estado, and $O$ Globo filter down to newscasts, radio,

\footnotetext{
2 As noted by Biroli and Miguel, researchers should be wary of two assumptions here, namely that a) the mainstream media conglomerates are completely centralized, unidirectional in their coverage and hegemonic in Brazilian news discourse, and b) that the electorate and the public opinion are tied strictly to that hegemonic discourse (Biroli and Miguel, 2013, p. 79). However, for the purpose of detecting informational cascades amongst audiences, the largest media outlets and their discourses are undeniably the logical place to start, all the while bearing in mind that production of news and consumption of news are two decoupled stages of meaning production, two separate, but determinate moments (Hall, 1980).
} 
and the regional and metropolitan press. Folha's and Globo's sites are furthermore the most visited Brazilian news sites, miles ahead of the entrepreneur political news blogs and online news platforms mentioned above (Newman et al., 2017, p. 107).

In the sampling, I leave out broadcast and weeklies, not because they do not matter, but because their particular formats filter the coverage of political matters much tighter than do the newspaper format. TV newscasts, for instance, are limited to specific time slots, and will balance political news with other topics, thus giving incomplete pictures of national politics on days where other issues congest the media agenda-sports, international terrorism, natural disasters, etc.

In sum, in order to assess how informational cascades propagate throughout a totality of media texts, I sample all front pages from Folha, Estado, and O Globo-the three main national papers of Brazil-and, furthermore, sample all printed and web-published articles in Folha and Estado dealing with news on national corruption and the impeachment proceedings (this leaves out stories on corruption abroad, e.g. the Panama Papers, as well as corruption in the international soccer association FIFA). The sample period contains the six months of front-page items up until the Lower House of Congress voted on the impeachment (on April 17, 2016), while the article sample comprised the period October 2015 to May 12, 2016, when the Senate ratified the vote of the Lower House. The total sample includes 8,800 news items, and more than 1,300 front page items, all dealing with news on political transgression and corruption.

Content analysis of front-page material provides an index of how salient each issue or story was on the national media agenda because the front pages of the three national newspapers signal importance and drive the Brazilian media agenda in general, as discussed above. The article count, meanwhile, provides an index of how attention to all cases of corruption was allocated, including the cases that did not make it to the front pages. The content analysis of articles samples news items and political commentary (but not editorials) in Estado and Folha, leaving out $O$ Globo in order to avoid excess data redundancy ${ }^{3}$. Both data sets reflect the distribution of media attention and the editorial and journalistic selection processes, which are instrumental in setting up an information cascade in public spheres.

\section{Framing and coding}

As shown by Iyengar (1990), the framing of news influences audience members' assignment of responsibility. Therefore, the articles and the headlines were coded by associating each news item with the object of the investigation, that is, the individual or party framed as responsible. Not surprisingly, most articles and headlines about corruption

\footnotetext{
${ }^{3}$ After an initial sampling period where 500 news items were collected from Folha, O Globo and Estado, the corpus was determined to be more than sufficiently saturated (Glaser and Strauss, 1967), and O Globo was left out of the article count in the rest of the sampling period to reduce redundancy.
} 
point to the transgressions of specific politicians, while a group of news items deals with the Petrobras corruption probe en bloc without explicitly attributing responsibility to a specific actor. Some news items mention multiple cases, but this was deliberately reduced in the coding process in order to avoid a qualitative weighting of each news item in the corpus (which would render the large sample unwieldy). Thus, despite overlaps in a fraction of the sample, the news items were coded as pertaining to only one case each ${ }^{4}$.

The coding of items does not go to the level of detail in framing analysis proposed by authors such as Entman (1993), nor does it include the many variations of organizing discursive principles through which occurrences are constructed and organized as meaningful events in news items (Tuchman, 1978, p. 193ff). Although the competing framings of the impeachment and the Lava Jato case are highly interesting (see Rizotto, Prudencio and Sampaio, 2017; Fontes, Ferracioli and Sampaio, 2016), I will argue that the framing of single news items are unlikely to be of interest to research. Normally, frame analysis aims at detecting whether and how audiences are swayed by exposure to alternate, competing frames concerning a political issue. However, such a conceptualization of audiences assumes that audience members have not already formed strong opinions about the issue, and the assumption is really researchers' artificial sequestering of the audience (Sniderman and Theriault, 2004, p. 141).

Competing frames were clearly present in the public debate; e.g. frames claiming a coup d'état versus a constitutionally legitimate impeachment, or frames projecting a strong Judiciary as protagonists competing with frames where the Lava Jato prosecutors and judges were cast as ideologically driven and vindictive crusaders or justiceiros. Given the extreme exposure of the case, it is very likely that audiences have met a large range of news on various platforms, and this would mean at least some exposure to heterogeneous framings. Although it would be possible to study the relative weight of frames in the sample texts, as long as "artificial sequestering" of the audience is impossible, we cannot gauge the effect of the different frames found in the sample. Ultimately, in the case of the Lava Jato probe and the impeachment process, it is highly unlikely that any one journalistic framing would produce any effect at all, since the case is

\footnotetext{
${ }^{4}$ Some actors had a range of different scandal cases or political transgressions covered by the media - Lula and Rousseff in particular, as well as Renan Calheiros. Because of this, some news items and columns mention several cases, but the coding of each item was then defined solely by the case highlighted in the headline or the lead, which usually refers to the most recent and actual event (such as a testimony, a leak, or investigation process). This means that, in principle, some cases appear more frequently in the material than the figures reported here suggest at first glance; the best example of this is the many items covering the impeachment that also mention the corruption of Petrobras, although this element was legally outside of the impeachment proceedings. The number of news items connecting Rousseff to the corruption in Petrobras is therefore even higher than the figures reported here suggest, and the same goes for Cunha, whose trial was often mentioned in news items dealing with other political actors. This research design opted for a strict coding with one case (or frame) per item in order to avoid having to equilibrate the weight of thousands of news articles-a task that would move towards a qualitative analysis rather than a quantitative one and would only exacerbate the finding of skew in the media attention to cases.
} 
so central to the contemporary public debate of Brazil, and audience members would be likely to have formed opinions before encountering specific texts.

\section{Historical context of the infostorm of impeachment}

Two historical precedents must be mentioned in order to explain the context of the impeachment and the corruption cases embroiling national politics in Brazil. The first precedent is the Mensalão case of 2005, which revealed a kickback scheme supporting the coalition management of the Lula government. The case attracted sustained media attention and was hailed as a milestone in Brazilian accountability and combat against corruption, but it also became a fix-point of ongoing negative framings of PT (Biroli and Mantovani, 2014; Feres Júnior and Sassara, 2016b; Michener and Pereira, 2016). In the decade following this scandal, mainstream media (such as Veja, Globo's various outlets, and Estado) exhibited increasing hostility toward the PT governments (e.g. Albuquerque, 2013, p. 5-15; Araújo, Costa and Fittipaldi, 2016, p. 105; Miguel and Coutinho, 2007, p. 103; Porto, 2012, p. 172). The Mensalão case went to trial in the Supreme Court seven years after being revealed, its crowning moment being the declaration of the verdicts, when a number of PT leaders, bankers, money launderers, and Congressmen from the government coalition were sentenced. This was lauded as an exception to the rule of impunity prevailing for the political elite in corruption scandals (Damgaard, 2015b; Pereira, Rennó and Samuels, 2011).

President Dilma Rousseff had started her first mandate in 2011 with a tough-oncorruption stance, firing many ministers involved in scandals (Araujo, Costa e Fittipaldi, 2016). Perhaps aided by this stance, Rousseff had weathered the storm of the Mensalão trial in 2012, albeit not without losing some public support (Avritzer, 2016, p. 44). However, six months after the sentencing of the Mensalão trial, a series of street protests occurred in the state capitals of Brazil. Initial protests against the price of bus fare in São Paulo picked up steam and erupted into national protests during June 2013, with millions in the streets-numbers unseen since the 1980s and early 1990s. The protesters were not united under any single banner, as the multitude in the streets branched off from the topic of public transportation fares (Saad-Filho, 2013). However, the mainstream media interpreted the street protests and online representations of these protests as being focused on corruption, inadequate public services, and governmental overspending (especially on the World Cup prestige construction projects) (Avritzer, 2016, p. 77).

The topic of corruption kept re-appearing at inconvenient moments for Rousseff's PT-led government. Five months before the presidential campaign kicked off, in March 2014, a money-laundering scheme was uncovered by police agents in Curitiba. The scheme had ties to the very top of the state oil company Petrobras, with one Petrobras director, Paulo Roberto Costa, caught red-handed destroying evidence. Costa opted for a plea bargain in order to reduce his eventual sentence, revealing a cartel of companies that 
colluded in tenders to share overpriced subcontracts in exchange for kickbacks to political actors. In November 2014, CEOs and presidents of seven of these companies were arrested, based on the information provided by a chain of testimonies initiated by Costa.

The press treated the testimonies of the Petrobras case as evidence that could swing the elections, and the scandal, therefore, had a dominating position in the election coverage, especially in the weekly press. In a historically close race, Rousseff won the second turn over Aécio Neves, but the former immediately faced calls for impeachment due to her perceived involvement in the Petrobras case, as former head of the company's Administrative Board. The losing candidate's party, PSDB, filed a number of petitions proposing to annul the elections, also based on exposés of the Petrobras case. After her re-election, the opposition lacked "the smoking gun" pointing to the President's involvement in the disclosed corruption at Petrobras, but several leaks from the investigations cast suspicions of corruption upon Rousseff's party, the PT.

Following the inauguration of Rousseff in January, the PT lost control of the important position of President of the Lower House of Congress. The evangelical leader Eduardo Cunha of PMDB assumed this position, and he soon became the target of leaks alleging his involvement in the Petrobras graft. As the year 2015 progressed, more investigations followed, and evidence and testimonies were continuously made public by the task-force of the Lava Jato case and the federal courts handling the case. This information was put to good use by journalists in the mainstream media-to a large extent, as shown in the following section, homing in on the President's party, although all of the most important parties from opposition and government alike seemed to have had stakes in the kickback scheme.

\section{Findings}

In the six-month period of the sample, 1176 front page items of the three major Brazilian newspapers were identified, all dealing with the corruption of the main political actors, the Petrobras scandal, or the impeachment. In the same period, 150 other items dealt with corruption allegations or probes against other actors (governors, senators, and mayors foremost among these) as well as six headlines alleging corruption of the then Vice President, Michel Temer. The company most frequently denounced for corruption in the headlines was Odebrecht, but this was nowhere near as frequent as news items on the corruption of politicians (despite being logically connected).

At the beginning of the sample period, in October 2015, the front pages and articles treated a diverse range of corruption subjects: Lula, Eduardo Cunha, the parliamentary investigation of Petrobras, as well as the fiscal delays that made the Congressional audit body TCU reject the accounts of the state. However, the diversity was gradually reduced, as the attention of the sampled media outlets gravitated towards a few select cases. 


\section{Graphic 1 \\ Frequency of news items on corruption cases on the front pages of Folha, Estado, and O Globo, October 2015 till April 2016}

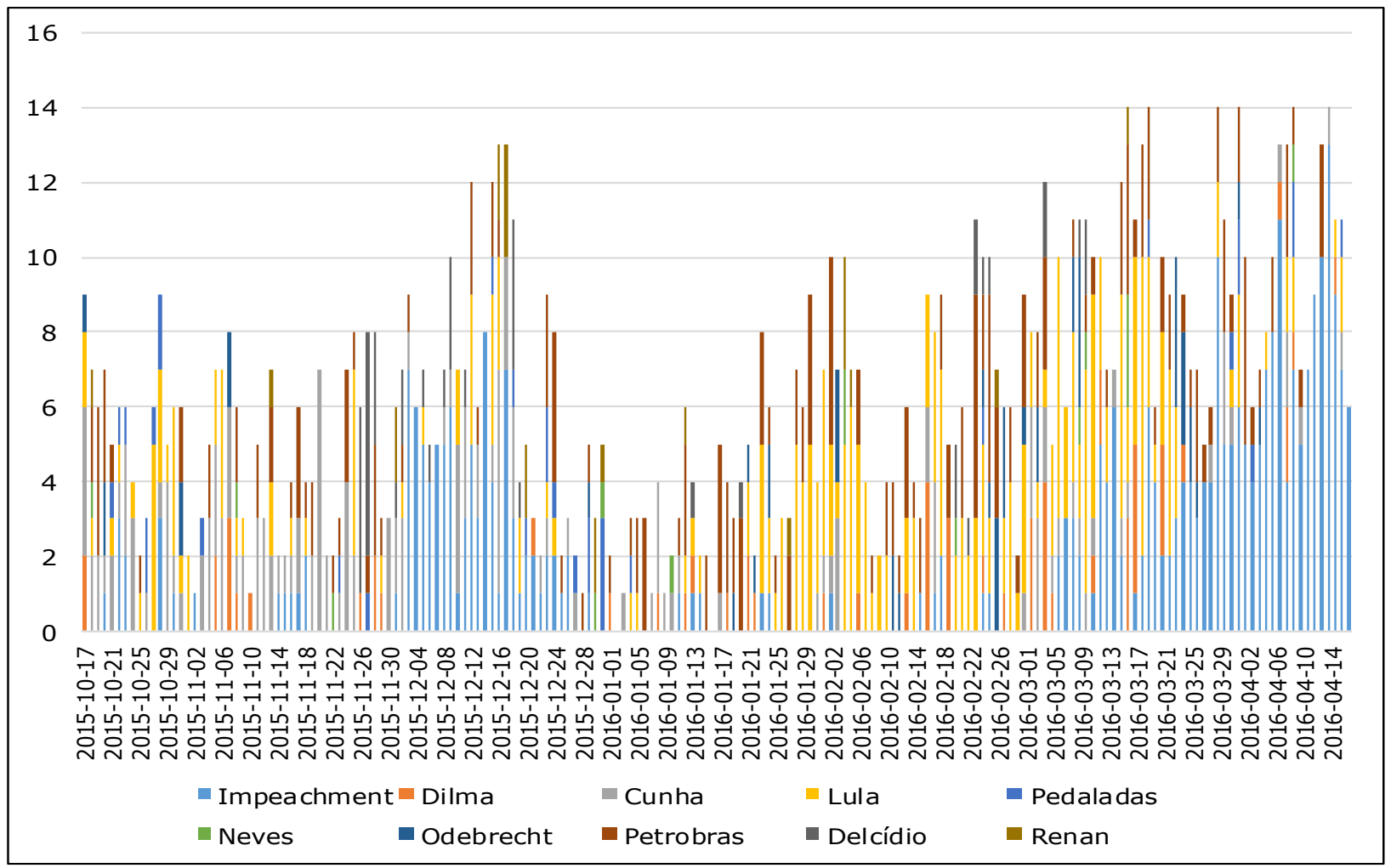

Source: Author's database of front pages.

As discussed in the theoretical section of this article, the information flows leading to cascades must be understood as dynamic phenomena. This means that when signals are amplified, other signals may be attenuated and eventually lost in the din, as this graph of the most covered corruption cases demonstrates: The attention to Lula and Cunha continued into November, with a spike of attention as the PT senator Delcídio de Amaral was arrested in the Lava Jato probe, followed by peaks of media interest in the first half of December, when Cunha signaled the start of the impeachment process. The various signals about corruption surging in October and November were drowned out in early 2016 as the newspapers dedicated their attention to cases related to Lula. The zika virus scare attracted attention in February, which meant that the front pages had a brief lull of attention to corruption. The graph demonstrates that on March 4, 2016, the moment that Lula was taken to testify in São Paulo airport, following the arrest of PT's marketing expert, the intensity of media attention to corruption increased and, shortly thereafter, decisively shifted its focus towards the question of impeachment.

The pivotal point of this graph is the days following the leak of recorded 
conversations with Lula, on March 16, where Lula's cases (yellow bars) began to be overtaken by headlines dealing with the impeachment (in blue bars). From that point on, impeachment news gathered speed and grew tremendously, dwarfing and eventually in April completely suppressing other news about politics or the corruption of the political actors assuming the mantle of the Presidency.

By comparing the relative frequency of headlines and news items about impeachment and corruption in the President's party, PT, to the coverage on other investigated politicians, it is clear that the mainstream media to a large degree reproduced and amplified the framing of the political game set in motion by the political actors rooting for impeachment. In the table below, the frequency of front-page items for each of the main actors' corruption cases is summed for the sample period. Outside of the PT, the most frequent corruption cases in the headlines dealt with Congress Presidents Cunha and Calheiros (both belonging to the PMDB), opposition leader and presidential runner-up in 2014 Aécio Neves, and the main subcontractor Odebrecht (from the cartel organizing the kickback scheme). The issues of impeachment and fiscal delays (the so-called pedaladas, described below) are separated from the news items concerning Dilma Rousseff's alleged corruption:

Table 1

Summed frequency of front-page news items concerning corruption cases in Folha, Estado, and O Globo, October 2015 till April 2016

\begin{tabular}{|c|c|c|c|c|c|c|c|c|c|}
\hline Impeachment & Dilma & Pedaladas & Lula & Petrobras & Cunha & Odebrecht & Delcídio & Calheiros & Neves \\
\hline 327 & 61 & 33 & 261 & 206 & 160 & 48 & 43 & 22 & 15 \\
\hline
\end{tabular}

Source: Author's database of front pages.

Only Eduardo Cunha had visibility in the headlines close to the President's, though he escaped the limelight while gradually steering the impeachment proceedings in the Congress. While news attention to Cunha remained mostly steady during the period (a total of 160 headlines distributed across the six months), news about Lula (total 261) and then about the Petrobras investigations (206 headlines total) eventually eclipsed news about Cunha's corruption cases, starting at the turn of the year.

Turning to the findings of the second data set, the sample of articles in Estado and Folha, we see the same pattern. Despite a range of involved actors, impeachment and corruption in the PT dominated news in the period. Most notably among these were Dilma Rousseff's mentor, ex-president Lula (950 news items in total), and the government spokesman senator Delcídio do Amaral (280 total). 


\section{Graphic 2 \\ Frequency of news items in Folha and Estado (web and print total) for key actors related to corruption and impeachment}

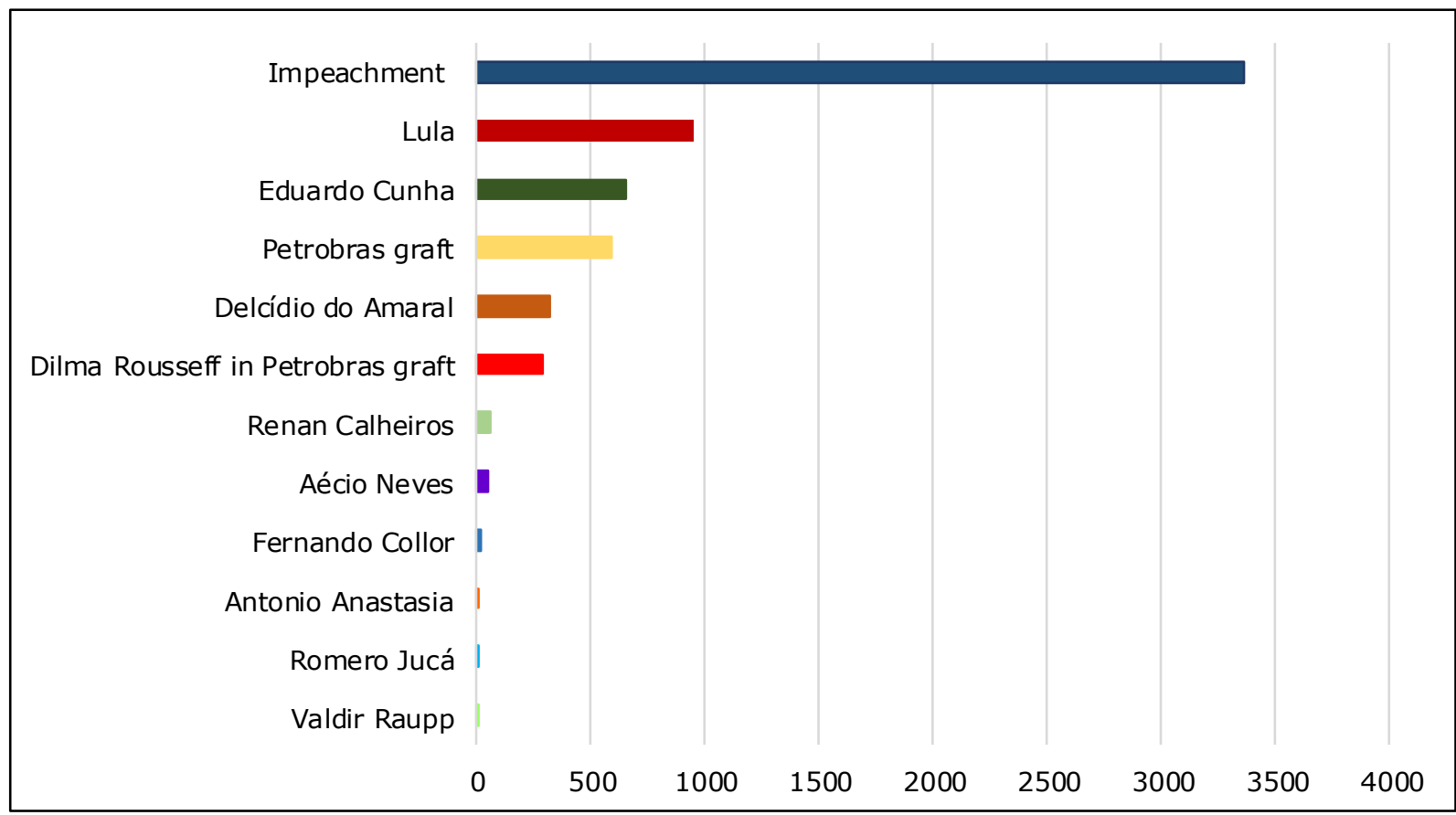

Source: Author's database of news items on corruption and impeachment.

The only story to rival those about the PT was the composite news narrative consisting in 600 items dealing with Eduardo Cunha. News on corruption in Petrobras in general, most frequently mentioning PT and/or PMDB with no specific politicians associated, reached 595 during the sample period. Items concerning Dilma Rousseff's involvement in the Petrobras graft and laundered money from the Petrobras scheme feeding her 2014 campaign reached more than 290 items in total, while impeachment news items numbered more than ten times that figure (3369) in the two news outlets.

This intense focus on these four persons dwarfs by a considerable margin the rest of the investigated politicians in the political elite. At the top of the second tier, Renan Calheiros was the focus of over 60 news items, just ahead of Aécio Neves. While Neves was only subjected to an investigation later in the Petrobras probe, Calheiros accumulated investigations in 12 cases of corruption. Other key politicians investigated for corruption (senators Raupp and Jucá of PMDB, and Anastasia of PSDB, for instance) did not appear half as often as Renan and Aécio in the news. Like the once-impeached President, now senator, Fernando Collor de Mello of PTB, these third-tier politicians were the objects of less than a total of 20 news items each across the two news outlets.

In comparison, the sons of the ex-president Lula (Luís Cláudio and Fábio Luís) had 
more (negative) traction with media, despite never running for public office: Allegations and investigations targeting the ex-president's sons were the topic of 73 and 36 articles in the corpus, respectively. In relative terms, attention to the impeachment of Dilma Rousseff is greater than all news topics concerning corruption. The ratio between the attention paid to the four most prominent scandals (Dilma, Lula, Cunha, and Delcidio) is thus 9:3:2:1. While the ratio between news on Dilma's and Aécio Neves' scandals was 50:1, the ratio between news on Lula and Neves was 19:1, and Cunha relative to Neves 12:1. The senators Romero Jucá and Valdir Raupp were almost lost, 500:1 in relation to impeachment news, and about 250:1 in relation to news on Lula.

The former Vice President Michel Temer, who in May 2016 ascended to the Presidency, rarely made the headlines for his relations to corruption cases during 2015 and 2016, though many testimonies in the corruption probe mentioned him. The same was true of the rest of the PMDB politicians, again despite being mentioned in testimonies for benefitting from the Petrobras graft. Media attention only shifted towards them as they took cabinet positions with Temer's ascendancy. That attention had effects, however: within 34 days of Temer seizing power, three ministers had stepped down. Most prominently, the minister of Planning and Budgets, Romero Jucá, had to take his leave after twelve days as minister, because recordings where leaked in which he discussed how to stop the corruption probe from reaching himself and his allies. The very same Jucá, however, maintained his seat in the Senate, and participated in the Senate's verdict against Rousseff. At the top of the second tier, Renan Calheiros was the focus of over 60 news items, just ahead of Aécio Neves.

\section{Information value in scandals}

Having shown that a bias in the distribution of attention to the range of political corruption scandals was evident in the mainstream media, it is pertinent to ask: What reason might the media outlets have for such a biased coverage? Why was information on impeachment and PT corruption valued so highly by media actors, and how could the bubble of information developing around the impeachment proceedings grow so huge? The mechanism of information cascades is one piece of a puzzle to which I now add the concept of informational value. By doing so, the analysis of the specific information cascade structure is supplemented by the theoretical question of how information in such cascades emerges as important and valuable for media actors. In the following, I will consider disclosed information in corruption scandals as assets, that is, elements which hold value to media actors and political actors alike. Based on observations of the contemporary Brazilian media system (Albuquerque, 2011; Lattman-Weltman and Chagas, 2016), I also discuss how this information value is modified by systemic and commercial factors.

Scandalous revelations and media exposés contain information that can potentially be part of horizontal accountability processes such as impeachment, court trials, or judicial 
actions in electoral courts. Corruption scandals also involve the dimension of vertical, electoral accountability (Mainwaring, 2003) to the extent that voters remember scandals and punish involved candidates by denying them votes. However, this dimension is notoriously weak in Brazil (Rennó, 2011; Winters and Shapiro-Weitz, 2013), and so disclosure of corruption is more likely to have a political effect through horizontal accountability.

The processes of horizontal accountability institutions are not merely legal, but also deeply political in nature, and their consequences are furthermore both reflected and shaped by the media trajectory of the scandal (Thompson, 2000): sustained coverage across all media outlets is in principle more likely to generate consequences than disclosure in fits and starts, because the sustained attention is more likely to push institutions and civil society into action. When an intra-media cascade of recycled coverage creates such a sustained media storm (Walgrave et al., 2017, p. 9), it is theoretically more likely that the scandal triggers accountability processes.

The potential of disclosed information on corruption to wreak political havoc or trigger trials in courts or accountability institutions is neither necessarily nor sufficiently determined by its belonging to categories of disinformation (which is intentionally false) or misinformation (unintentionally false), though the likelihood of falsification certainly might influence the value. Even information that can never be verified might have political consequences. In fact, information cannot even be defined as "well-formed, meaningful and truthful data" (Floridi, 2011, p. 80) because contextual factors such as imparting processes, intentionality and semantic layers have to be taken into account (Fallis, 2011). The front page of the weekly magazine Veja in October 2014, "revealing" the PT presidents' knowledge of the Petrobras corruption, is a prime example of this, because private knowledge is hardly verifiable, but the pseudo-disclosure of Lula and Rousseff's knowledge ultimately had political, rather than epistemological, intentions. The exposé was based on one of many testimonies made by the original money launderer in the Petrobras case, although his knowledge of their supposed awareness was in turn based on signals from the Petrobras CEO.

By removing the predicate "well-formed" from the definition of information in Floridi's "truthful and meaningful" category, information as a concept is thrust towards the notion of framing, discussed above (Entman, 1993; Sniderman and Theriault, 2004). The money launderer's information about Lula and Rousseff was framed as scandalous, although lacking in hard evidence.

Thus, information about political transgression can be framed through journalistic and editorial production as highly corrupt, though the political action in question might not be verifiable or even criminal in the technical sense. Through certain framing devices, information can even be formed and then imparted exactly and truthfully, but partially, in a way to create states of potential misinformation with the audiences. A range of leaks in the Lava Jato case, stemming from the prosecutors and investigative authorities, has been 
criticized for creating such states of misinformation, because the leaks were framed as truthful by the media, no matter the vested interests of the whistle-blowers and the individuals leaking the information (Guimarães et al., 2016).

The information value of scandal also implies the anticipation of value, and the $a$ priori realization of this value. Realizing value a priori means journalistically narrating the consequences of, say, a scandal, before those consequences manifest. This was quite visible in the coverage of Lula's alleged ownership of a ranch and a beachfront apartment during January and February 2016: Seven months before the Federal Police even indicted Lula, on August 27, the possible political consequences were all the rage of the mainstream media (as seen in Graphic 1), because the information about these estates and their ownership was potentially lethal to Lula's plan about running for Presidency in 2018. Anticipating the value of information is part and parcel of how news media operate during scandals, because any information element in a scandal is only as interesting as its potential value. The potential value of information is thus tied to perceptions of whether allegations will stick, and expectations about whether a scandal will generate effective accountability processes.

In other words, information value derives from what could be termed the disruptive potential of that information. The disruptive potential depends on the relevance of disclosed information to institutional processes (what can be included, what will count as evidence, etc.), and the eventual trajectory of the processes triggered by disclosure (what is the ultimate outcome, e.g. how much political damage can the disclosed information inflict). Those questions are also relevant in the editorial processes and the social media's redissemination after publication (what disclosed information merits a follow-up story, what will be re-tweeted, liked, and shared, etc.).

This anticipated potential of information is tied to another aspect of information value: information about the perceived center of political agency, such as the Presidency, is valued higher than information about more marginal actors. The proximity to perceived centers of power goes a long way in determining what information will be transmitted in the mainstream medias' information flow. Albuquerque (2011, p. 91) has observed that presidentialism seems to be an important, but under-researched parameter when studying media-politics relations. With the concepts of information value and perceived disruptive potential, I suggest one (non-exhaustive) explanation for understanding the peculiar importance of presidents in this kind of media system: within a presidential system, editors and media organizations want to pay special attention to cases that might disrupt the president, because such information presents far greater and more exceptional consequences than in parliamentary democracies, where government turnover is part of the regular institutional set-up. A case of an unstable president demands attention in virtue of the institutional exceptionality and will provide raw and juicy material for scandal coverage. Such coverage reinforces the notion of the presidency as the locus of political agency. Regardless of which other political forces actually dominate, this draws away 
attention from party politics and towards the person of the president.

The predilection for presidential affairs may be a strategy to obscure the real party allegiances of the media organizations reporting on politics, but it could also be the result of a conscious marketing strategy: as noted above, the prestigious newspapers of Brazil have taken critical stances towards PT presidents for a decade, and this re-emergence of party/press parallelism (or repartidarização) could be a way of bolstering a brand and keeping politically engaged readers interested in the newspaper as a product (LattmanWeltman and Chagas, 2016). This trend creates a commercial pressure for a certain kind of political news, in the form of exposés that tarnish the PT, given that elite newspapers are more likely to sell actual copies to the metropolitan business and political elite which traditionally supports center-right ideologies.

There are more commercial dimensions to scandals: a scandal, to editors, represents an attention-grabbing pool of different stories that can be mined continuously with a certain amount of recycled information. Therefore, a scandal is a cheap investment compared to the amount of stories it can yield (Beale, 2006, p. 401). In terms of audience, the newspaper with a scandalous headline is assumed to sell more, meaning more advertising revenue. Furthermore, as scandals usually beg the question "did somebody else know this?" it is easy to escalate the scandal to other actors or to the national level, meaning a greater potential audience. If advertising is a centerpiece of the newspaper or networks business model, then scandals will be especially in demand in situations of stagnant or dropping audiences-a situation that applies to roughly all of the traditional media after the advent of the Internet.

In sum, disclosure of scandals holds value both for political actors and in the commercial strategies of elite newspapers. Even with a varied palette of scandals, information that could disrupt a presidential term would be of special interest to this part of the media system. In the analysis of the content study, I have shown that only a few of the many corruption cases of national interest were covered extensively by the three newspapers and the online news platforms of Folha and Estado because Lula and the impeachment drew all the attention. The cascade of news items dealing with these topics gradually eclipsed all other news about corruption on the media agenda, and this section has considered why these two storylines were all the rage from the perspective of the Brazilian media. Given that the political actors of Brazil are aware of these dynamics, this begs the question of how disclosed information is used for political gain. In the next section, I will analyze how the information cascade could be interpreted as a part of a deliberate intra-elite strategy specifically aiming to eclipse questions of political accountability.

\section{Triggering scandals to create cascades and coalition reconfiguration}

As argued by Balán (2011), denunciations of corruption provide political actors with a tool for changing sides in a political race. Scandals, in the analysis of Balán, are triggered 
by the competition between government actors for power and resources. Identifying a significant pattern of correlation between scandal frequency and high intra-government competition in Chilean and Argentinian politics in recent decades, Balán's model also applies to the Brazilian case (as shown by Araújo, Costa and Fittipaldi, 2016): scandals are a means to an end-and that end is not cleaner politics, but re-distributing political influence and resources 5 . Balán's results echoed Peruzzotti, who considered media exposés "an instrument of the "politics by other means" that ultimately feed political cynicism and apathy" (Peruzzotti, 2006, p. 256), and Waisbord's analysis of Latin American watchdog media: where media provide channels for politics by other means, scandals in reality express the vested interests of elites rather than the ideals of watchdog journalism (Waisbord, 2000, p. 233). In the Brazilian context, Porto underscored the same problem and also called to attention the problem of "[c]ollusion between journalists and officials [that] frequently prevents watchdogs from barking even when evidence of wrongdoing is available" (Porto, 2011, p. 111).

In the following, I stipulate that Brazil's political actors (in Congress as well as in courts and accountability institutions) are aware that media scandals can bring about an infostorm. Given this, it makes sense to consider the complex interplay of investigations, denunciations, leaks and scandal as a cascade of signals that were deliberately emitted to create the particular political ambience that lead to the ousting of Dilma Rousseff. The point of this is to show how identifiable actors that strategically stoked media interest fueled the cascade of corruption information, and how this information transformed from rumor and anticipated information (in the sense described above) to hard financial and political facts.

Employing this perspective, the intertwined narratives of the impeachment and the Lava Jato scandal may be unpacked in the following manner: A group within the political elite of the Brazilian Congress, centered in PMDB, aired the idea of impeaching President Rousseff after the 2014 elections, and the idea rapidly caught on in the media. How exactly to delimit this group is not possible at this point, but we may surmise 1) that said group of politicians believed it to be possible to remove the President through judicial means (either in the Supreme Electoral Court or through impeachment); 2) that the group eventually deemed it advantageous and even necessary to wrench power from Rousseff because winning the presidency could potentially stop corruption probes and investigations against themselves; and 3 ) that several members of the group of politicians held key positions in Congress, allowing them to control impeachment proceedings against the President.

By combining the Petrobras denunciations against the President's party with critique of her fiscal policy, a splinter group of PMDB (PT's main coalition partner) prepared

\footnotetext{
${ }^{5}$ In this case, the outcome of scandals predicted in Araújo, Costa and Fittipaldi (2016) was actually inverted: The re-distribution of cabinet positions, initiated by the jump-ship strategy that became viable with the Petrobras scandal, benefitted, at the time of writing, the parties most distant ideologically to the Executive, because the Executive as a whole was replaced.
} 
to jump ship (in the strategical sense of Balán, 2011, p. 462) and declare themselves as opposition. The first PMDB politician to make that move was the President of the Lower House, Eduardo Cunha, on July 17, 2015. This had, not coincidentally, the effect of displacing the media spotlight, because Cunha's case in the corruption probe had advanced the most in the Supreme Court, and the court handling the Lava Jato case had published the testimony of a CEO confirming paying bribes to Cunha the day before his break with government. Furthermore, Cunha's move followed the primary hypothesis proposed by Balán (2011), because it forced the President to concede more space to PMDB in cabinet, in hope of stabilizing and maintaining the government alliance.

Cunha then began to harass the Rousseff government by signaling the viability of the impeachment petitions he had received as President of the Lower House of Congress. Through his position, he was vested with the power to deny or proceed with the impeachment process, but only actions pertaining to Rousseff's current mandate could constitute a legal ground for impeachment. The fiscal delays called pedaladas fiscais turned out to provide a ground for impeachment. During 2014, the Finance Ministry had expanded a practice of delaying transfers of funds between the National Treasury and public banks. Temporarily shifting the burden of the programs onto other public actors, the delays somewhat masked the fact that the state accounts were in bad shape after years of plummeting oil prices and the great slow-down of the Chinese economy, the most important export market of Brazil. Denounced in Estado as an illegal budget maneuver, the government, however, stopped that practice in 2014, but in October 2015, the Congressional audit body TCU (Tribunal de Contas da União) rejected the government accounts of 2014 because of the delays.

The TCU auditors argued that the delays and credit maneuvers transgressed the Law of Fiscal Responsibility (Villaverde, 2016, p. 179ff, 223), and this fed a new wave of impeachment petitions. A trio of lawyers elaborated the argument that other situations (in 2015) in which the government had obtained credit without prior ratification by Congress could be considered criminal, as could other maneuvers shifting the burden of state credit. Thus, the negative evaluation of Rousseff's fiscal policies and management of state accounts was chosen as the argument for the eventually successful impeachment petition, in the absence of any investigations targeting her specifically in the ongoing corruption probe. The President herself was allegedly responsible for the practice, according to the petition, and both this claim and the legal grounds became hotly contested. The practice of delaying payments is wide-spread at both the federal and state levels in Brazil, and the President's hand in cooking the books through quite specific fiscal transactions was debatable.

Having used the petition for levering support from PT parliamentarians in November 2015, Cunha faced his own disciplinary trial in a Congressional committee-a trial that would eventually annul his mandate. PT members of the committee voted against Cunha, which started a Congressional trial; in retaliation, he opened impeachment 
proceedings on December 2, 2015. At that moment, 32 different impeachment petitions had been produced by various actors. Most of them alluded to the Petrobras graft, as did the petition that Cunha allowed to proceed. So, despite the dearth of hard evidence in 2015 that could topple Rousseff, and despite the clause that restricts impeachment to acts of the current term, the Petrobras case still became entangled with impeachment proceedings, through the following sequence of public signals:

\section{Sequence of signals in 2015}

1. (January onwards) Continued investigations of Petrobras $\rightarrow$ Media focus on PT and Rousseff

2. (March 8 and March 15) Protests call for the impeachment of Rousseff, eclipsing the investigations opened into 47 politicians, the majority belonging to the PP

3. (June) Cunha is cited as involved in the Petrobras case in a plea bargain $\rightarrow$ Cunha declares himself in opposition to government and, thus, signals "jump ship" to his party $\rightarrow$

4. (July-August) Cunha signals that impeachment petitions are being considered

5. (August-October) Cunha and several other politicians are denounced in the Petrobras probe $\rightarrow$ The opposition signals support for impeachment and starts obstructing economic reform bills proposed by the government

6. (October) TCU rejects the government's 2014 accounts because of the fiscal delays $\rightarrow$ the eventually-accepted impeachment petition is handed in to Cunha, arguing for impeachment on the grounds of those delays

7. (December) A disciplinary process against Cunha is initiated in the Ethics Council of Congress $\rightarrow$ Cunha announces that impeachment proceedings will be opened

As parts of PMDB and other center parties of the government coalition followed Cunha's jump-ship strategy, the government lost support for any economic reform that could diminish a state budget deficit in 2015. Later, Rousseff's inability to pass bills then became the pretense for these coalition parties for abandoning the PT and supporting the Vice President's bid for power. Three processes unfolded simultaneously: the Lava Jato scandal, the looming budget deficit, and the impeachment. The processes tied together different bits of information in the political game set afoot by Cunha and the lawyers behind the petition, merging together the narrative that the state accounts were in bad shape, that Rousseff was responsible, and that her party, through corruption, had bankrupted the state oil company Petrobras, once the largest company in all of South America. Studies and opinion polls of the time show a correlation between the population's approval of government, the perception of negative news, and the Petrobras scandal (Baptista, 2017; 
Datafolha, 2016; Indicadores CNI, 2015a, 2015b) ${ }^{6}$.

The polls do not necessarily show that the Brazilian audiences confounded the facts of the nation's fiscal situation and the rumors of Rousseff's involvement in the Petrobras corruption, but it is clear from political discourse in the same period that large blocks of Congressmen from both opposition and former government coalition partners rallied around that narrative constellation. The public signal, sent by Cunha by accepting the petition for impeachment, was thus multiplied and disseminated by a growing group within the political elite. While these parliamentarians, predominantly from the center and rightwing parties, added their weight to the beginning cascade, they disregarded the accumulation of evidence in the Petrobras investigations against Cunha and PMDB leadership.

\section{Sequence of signals in 2016}

1. (February) Dilma Rousseff's marketing strategist is taken into custody in the Petrobras case

2. (February) Investigations into Petrobras corruption target Lula and PTs marketing expert $\rightarrow$

3. (March) PMDB breaks from government, signaling "jump ship" to the rest of the center parties $\rightarrow$ the rest of the government coalition partners leaves government

4. (April) 367 Chamber of Federal Representatives vote for opening impeachment proceedings

The suspicion that the group within the political elite of Brazil was interested in removing President Rousseff with the intention of saving their own hides was confirmed in May. The proof became breaking news soon after the new coalition coalescing in Congress, united under the name "O Centrão" and, led by Eduardo Cunha, replaced Rousseff with Vice President Michel Temer of the PMDB. That became evident with recent leaked recordings published by Folha on May 23, 2016.

The secret recordings were taped before the impeachment was executed, and featured a key witness in the Petrobras case discussing the removal of Rousseff with major political actors of the PMDB, such as Renan Calheiros and ex-president José Sarney. In the conversations, the politicians agree that it is necessary to end the corruption probes into the political establishment, which threatened to "put an end to the political class". Another

\footnotetext{
6 Public opinion polls in the period from the 2014 elections to the end of 2015 showed that $32 \%$ of the respondents noticed negative news coverage around the elections, which increased to $45 \%$ in late 2014 and then reached $72 \%$ in March 2015, an apogee that was maintained for the rest of the year. During the same period, President Rousseff's approval ratings in polls fell from around 50\% during the 2014 elections, $40 \%$ around Christmas 2014, to 12-13\% (Indicadores CNI, 2016; Datafolha, 2016) in March 2015, to 8-10\% in July-August 2015 (Datafolha showing the lower figure, surveyed in early August 2015; Datafolha, 2016, p. 14).
} 
key actor, the PMDB Senator (and later minister) Romero Jucá, stated on the recordings that it was necessary to "stop the bleeding" of the political class by changing government and ending the Prosecutor General's project of cleaning politics (Valente, 2016). With the leaks, it became apparent that the public signals about political crisis and the stated reasons for the impeachment, available to all Brazilians through the media, had an insidious subtext only known to elites, who aimed at ending the corruption probes by ousting the PT administration. Dilma Rousseff showed no sign of wanting to stop or curtail the probe while in office, not even as it targeted her party. From the leaked recordings of May 2016, we can conclude that the support for impeachment was not only a grab for power by the center-right parties of the governing coalition, but also an attempt at stopping the corruption probe from eventually reaching parties other than the PT.

It is noticeable in the abstracted signal sequence above that every time the PT, Dilma Rousseff, or her predecessor Lula were targeted by the Petrobras investigations, the momentum of impeachment grew, even though the eventually effective ousting could not be based in the Petrobras case. The mainstream media only amplified the apparent message of political crisis and instability, prioritizing news from the front stage concerning the President, rather than the backstage reasoning of the political elite for removing her. The crisis of the political scene supplanted itself unto the financial markets of Brazil, providing yet more arguments underpinning the impeachment. This dynamic, where intramedia information cascades pushed by intra-elite power games become a manifest force on stock markets, is discussed in the following section.

\section{Information and flows of the Brazilian financial markets}

The flows of information about a scandal's political consequences, and the anticipation of those consequences, are shared between media and the political system, broadly speaking, but these flows are also reflected in the speculation and bubbles of stock markets. Market reactions to different social proofs were readily visible during the process of impeaching Rousseff. Events on the political scene deemed important in the media triggered immediate reactions from actors on the financial markets, visible in aggregated financial indicators such as stock markets and exchange rates. In this section, I will provide two examples of this behavior of the Brazilian markets. During the impeachment process, traders and shareholders reacted to the publicly available signals with a view to the perceived negative economic conditions during the deadlock of the Rousseff administration. When news indicated impeachment of Rousseff as likely, Brazilian stocks increased in value, and inversely decreased in periods without news on the impeachment, because the Rousseff administration was depicted as unable to implement economic reforms.

The first example is the spike in Brazilian stock value the day after the impeachment petition was accepted (December 3, 2015). The São Paulo stock market Bovespa rapidly reacted to the news, breaking a steady decline of the preceding period, 
rising $3.29 \%$ on average within the day, with Petrobras preferred stock rising $6.12 \%$ and the Banco do Brazil leading with an $8.4 \%$ rise. As the Supreme Court intervened in the impeachment process shortly thereafter, and it became clear that the initiation of proceedings would only take place after the Carnival, the stock markets again declined (and the dollar-real exchange rate climbed). Later news, in February and March, heralding the impeachment of Rousseff (e.g. the imprisonment of Rousseff's marketing strategist João Santana on February 23, new plea bargains alleging corruption in Rousseff's campaign on March 4, and Lula's testimony the following day) likewise had the effect of breaking the trend in the declining stock market:

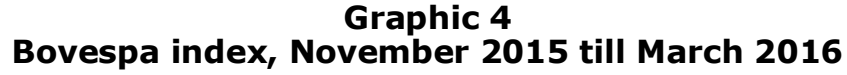

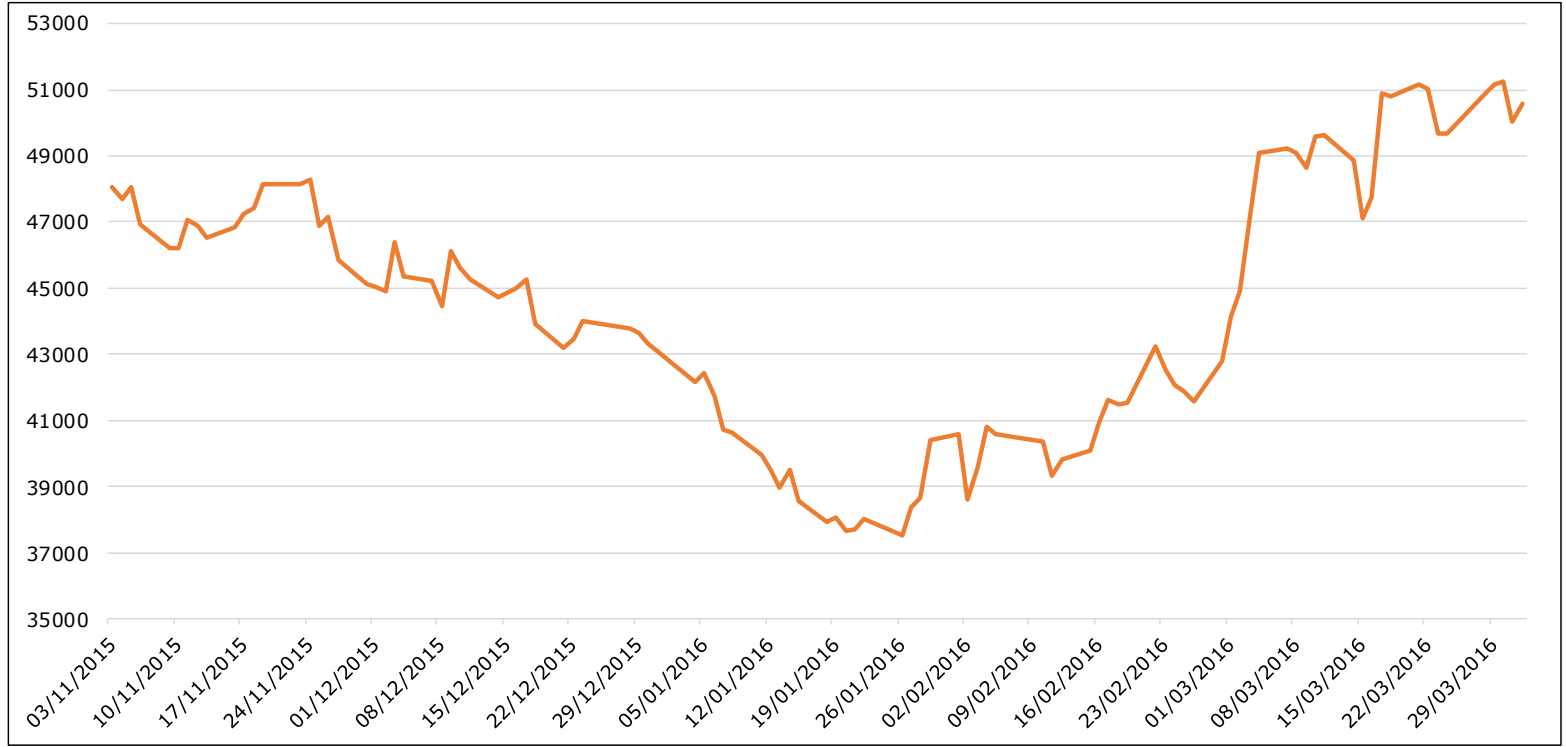

Source: BM\&F-Bovespa (Cotações).

Zooming in on the last days of Dilma Rousseff's presidency, the graph below gives a second example of the Bovespa index from the day of the vote for impeachment in the Lower House of Congress to the day of the corresponding vote in the Senate. In response to the Lower House's ratification, the Bovespa index rose again (with a 5-day interruption) until April 27, continuing the trend of March and April. On the $28^{\text {th }}$, the Central Bank chose to maintain the interest rate at $14.25 \%$ and the market cooled off for a fortnight, to rise sharply during the 2-day debate in the Senate preceding the removal of Rousseff on May 12: 


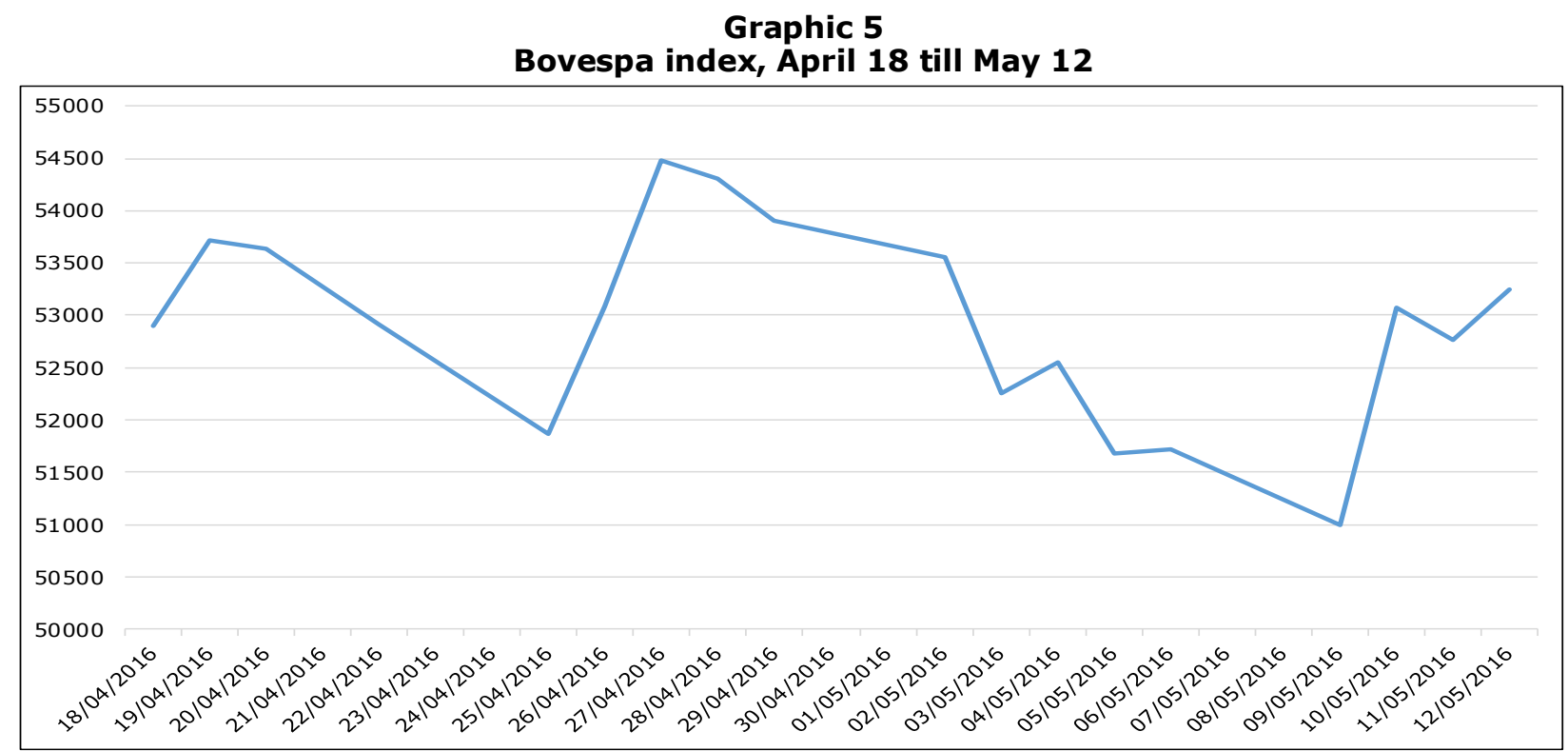

Source: BM\&F-Bovespa (Cotações).

Similarly, the exchange rate between the Brazilian real and the dollar mirrors the market activity and the possibility of impeachment: as the stock markets went down, the real steadily lost value vis-à-vis the dollar throughout the second half of 2015, and only recuperated this with, along with a string of negative news for Rousseff that started in February and exploded in March (UOL Economia, 2016).

The cascade mechanism is still based on the social proof gathered from media: traders perceive investment instability caused by scandal; then, other traders and algorithms pick up on these market tendencies, media report on those movements, and the market goes down en bloc, along with the currency. Not surprisingly, the actors of the stock market react on possibilities-in this case, on the possibility of impeachment, trying to buy stocks cheap before other actors realize that their value may increase after the impeachment. This explains the rapid spikes, rather than prolonged value increases, of the market: Short bursts of speculative activity and no real changes in the economic realities of Brazil, because the Congress stalled economic reform during the whole period while waiting for the impeachment. The traders' perception of scandal is of course modulated by media attention, and it is even amplified (through positive feedback) when journalists of financial beats publish news items connecting the market indicators to the political events of a scandal.

Although theoretically, the sudden concerted moves of shareholders scattered across the world could be mere correlation, I will argue that the events that gradually brought about the ousting of Dilma Rousseff were in fact the cause for these fluctuations, because they were internationally visible and of obvious consequence to the economic 
policies of Brazil. This could be interpreted as a second stage of the information cascade. The biased selection of news issues is not only closely correlated to the stock market and the exchange rate, but may actually have caused shorter bursts of financial activity in reaction to the impeachment news. The brokers, like the editors, were more agitated when the impeachment seemed more likely: the value of (scandal) information on the stock market, just like the media market, is anticipated, or potential, value.

\section{Conclusion}

This article has shown how Brazil's dominant media outlets in the period preceding the ousting effectively eclipsed questions of accountability by over-exposing the impeachment and the Petrobras investigations against PT politicians. As information about these issues cascaded between the media actors and on to the stock markets, other political actors went under the radar of the media, as did the urgent democratic problem of handing the government over to other elite actors also investigated in the Lava Jato probe. By disregarding information on these actors to the grave extent documented in this article, the media outlets amplified the cascade initiated by that very same group within the political elite, and made politics a matter of impeaching the President rather than holding all of the political spectrum accountable.

Thus, on April 17, 2016, 73\% of the Chamber of Federal Representatives voted in favor of the petition for impeaching Dilma Rousseff. Of the 511 representatives voting, virtually none cited the explicit justification of the petition-the delays of transfers from the Treasury to the public banks. However, scores of representatives stated that by voting for the impeachment, they voted against corruption, implicitly or explicitly reproducing the narrative that first emerged from the 2014 disclosure of corruption in the state oil company Petrobras. This narrative of the President's personal responsibility in either the corruption case or the delayed transfers was a recurring theme, although the allegations still lack substantial evidence. In fact, between the vote in the Chamber and the vote in the Senate, a technical report of the Senate's lawyers demonstrated that no internal document corroborated the theory of Rousseff's involvement nor any intentions in the Finance ministry or the National Treasury of masking budget deficits through the maneuver. Despite the report, on May 12, the Vice President Michel Temer took the mantle temporarily from Dilma Rousseff, ultimately riding the information cascade to the Presidency on August 31 with the final ratification of the Senate.

To sum up the present case study of the information cascade of the intertwined impeachment process and corruption scandals, the article has attempted to show that the concept of information cascades is fruitful for analyzing political scandals and that, moreover, the cascade phenomenon challenges preconceptions of the relations between media, political actors, accountability institutions, and publics. Accountability was hampered by the media, and the public opinion seemed not to matter much in this case, 
because the cascading of information from a subgroup within the political elite through media and into the financial markets accumulated and made it alluringly easy to disregard other information. Public signals sent by political actors and reproduced by media and financial institutions might really be part of an entirely different set of signals only known (or acknowledged) internally in the political field. By stacking such signals, political issues may be confounded and conflated in such a way that the media's anticipation and overvalorization of political disruption obscures both possible consequences and intentions behind the process leading to such disruption. Similarly, the inflated value of information about the perceived center of power will depreciate the value of news on other powerful political actors, diminishing accountability and transparency for the electorate.

What we see, then, is not the media informing Brazilian audiences about the combat on corruption, but rather a strong public with decision-making power (the Brazilian Congress) deliberating internally, through the media, about the solutions to the threatening corruption probes. Spinning off of the political reactions to the information sequences, the media attention was modulated by the perceived value of that information by media actors, and the information was then disseminated along cultural and political fault lines that shaped this information and excluded other relevant information in a systematic although not sufficiently acknowledged way.

In the extant literature analyzing scandals and media exposés, media hypes and storms, researchers have pointed out how such media phenomena are potentially harmful, because a topic can be blown out of proportion, leading to suboptimal political and social solutions. With the notion of information cascades, that is, an aggregate phenomenon that emerges from the range of signals emitted by political, economic, and media actors and institutions, it becomes clear that stakes are even higher. Information cascades may have damaging consequences that can impinge upon the equilibrium and survival of a representative democracy.

Mads Damgaard - Faculty of Humanities, Department of English, Germanic and Romance Studies, Portuguese and Brazilian Section. University of Copenhagen, Copenhagen, Denmark. E-mail: <mads.damgaard@hum.ku.dk>.

\section{Bibliographic references}

Abramo, C. "Brazil: A portrait of disparities". Brazilian Journalism Research, vol. 3, n 1, p. 93-107, 2007.

Albuquerque, A. On models and margins: comparative media models viewed from a Brazilian perspective. In: HALlin, D.; MANCINI, P. (eds.). Comparing media systems beyond the Western world. New York: Cambridge University Press, 2011. 
Albuquerque, A. "On behalf of the public: journalism and politics in Jornal Nacional interviews with presidential candidates". E-compós, Brasília, vol. 16, n² 2, 2013.

Araújo, C. M.; Costa, S.; FitTIPAldi, I. "Boa noite, e boa sorte: determinantes da demissão de ministros envolvidos em escândalos de corrupção no primeiro governo Dilma Rousseff". Opinião Pública, Campinas, vol. 22, nº 1, p. 93-117, 2016.

AVRITZER, L. Impasses da democracia no Brasil. Rio de Janeiro: Civilização Brasileira, 2016.

BALÁN, M. "Competition by denunciation: the political dynamics of corruption scandals in Argentina and Chile". Comparative Politics, vol. 43, n 4, p. 459-478, 2011.

BAPTISTA, E. A. "Corrupção e opinião pública: o escândalo da Lava Jato no governo Dilma Rousseff". Belo Horizonte. Master's Thesis. Fafich, PUC-MG, 2017.

BEALE, S. "The news media's influence on criminal justice policy: how market-driven news promotes punitiveness". William and Mary Law Review, vol. 48, n² 2, p. 397-481, 2006.

BikHCHANDANI, S.; HiRSHLEIFER, D.; WELCH, I. "Learning from the behavior of others: conformity, fads, and informational cascades". Journal of Economic Perspectives, vol. 2, n 3, p. 151-170, 1998.

Biroli, F.; MAntovani, D. "A parte que me cabe nesse julgamento: A Folha de S. Paulo na cobertura ao processo do Mensalão". Opinião Pública, vol. 20, n² 2, p. 204-218, 2014.

Biroli, F.; Miguel, L. F. "Meios de comunicação, voto e conflito político no Brasil". Revista Brasileira de Ciências Sociais, vol. 28, n 81, p. 77-95, 2013.

Boydstun, A. Making the news. Politics, the media, and agenda setting. Chicago: University of Chicago Press, 2013.

CABRAL, E. D. T. "Mídia no Brasil: concentração das comunicações e telecomunicações". Revista Eptic, vol. 17, n³, p. 16-28, 2015.

COTAÇÕES. BM\&F-Bovespa. (Online). Available at:

<http://www.bmfbovespa.com.br/pt_br/servicos/market-data/cotacoes/>. Access on: January 5, 2018.

DAMGAARD, M. "Multiple margins and mediatized transgression". Ephemera - Theory and Politics in Organization, vol. 15, $\mathrm{n}^{\circ} 2$, p. 411-434, $2015 \mathrm{a}$. $\overline{197-234}, 2015 b$.

"Narrating the Mensalão trial: configurations of corruption". Brasiliana, vol. 3, n 2, p.

Datafolha. Avaliação da presidente Dilma Rousseff - abril de 2016, P0813859. São Paulo:

Datafolha, 2016.

ENTMAN, R. "Framing: toward clarification of a fractured paradigm". Journal of Communication, vol. $43, n^{\circ} 4$, p. 51-58, 1993.

FAlLis, D. "Floridi on disinformation". Etica \& Politica / Ethics \& Politics, vol. 13, n 2, p. 201-214, 2011.

FERES JÚNIOR, J.; SASSARA, L. "Corrupção, escândalos e a cobertura midiática da política". Novos Estudos Cebrap, vol. 35, n², p. 205-225, 2016 a.

. "O cão que nem sempre late: o Grupo Globo e a cobertura das eleições presidenciais de 2014 e 1998". Revista Compolítica, vol. 6, n 1, 2016b. 
FLORIDI, L. The philosophy of information. Oxford: Oxford University Press, 2011.

Fontes, G.; Ferracioli, P.; SAmpaio, R. "Petrolão na mídia: o enquadramento de 18 meses da Operação Lava Jato nas revistas impressas". Agenda Política, vol. 4, n 3, p. 238-266, 2016.

Foucault, M. Power/knowledge: selected interviews and other writings, 1972-1977. Ed. Colin Gordon. New York: Pantheon, 1980.

GlASER, B.; StRAusS, A. The discovery of grounded theory: strategies for qualitative research. Chicago: Aldine Publishing Company, 1967.

GuIMARÃES, J., et al. (eds.). Risco e futuro da democracia brasileira: direito e política no Brasil contemporâneo. São Paulo: Fundação Perseu Abramo, 2016.

HALL, S. Encoding/decoding. In: HALL, S., et al. (eds.). Culture, media, language. London: Hutchinson, 1980.

Hansen, P. G.; Hendricks, V. F.; Rendsvig, R. K. "Infostorms". Metaphilosophy, vol. 44, n³, p. 301326, 2013.

HENDRICKS, V; HANSEN, P. G. Infostorms. How to take information punches and save democracy. London: Springer/Copernicus Books, 2014.

INDICADORES CNI. CNI/Ibope Avaliação do governo, setembro 2015. São Paulo: Confederação Nacional da Indústria, $2015 a$.

Indústria, $2015 \mathrm{~b}$.

CNI/Ibope Avaliação do governo, dezembro 2015. São Paulo: Confederação Nacional da . CNI/Ibope Avaliação do governo, março 2016. São Paulo: Confederação Nacional da Indústria, 2016.

IYENGAR, S. "Framing responsibility for political issues: the case of poverty". Political Behavior, vol. $12, \mathrm{n}^{\circ} 1$, p. $19-40,1990$.

KRISTENSEN, N.; MORTENSEN, M. "Amateur sources breaking the news, metasources authorizing the news of Gaddafi's death: New patterns of journalistic information gathering and dissemination in the digital age". Digital Journalism, vol. 1, n³, p. 352-367, 2015.

LATTMAN-WeltMAN, F.; ChagAS V. "Mercado futuro: a economia política da (re)partidarização da imprensa no Brasil". Dados, vol. 59, n² 2, p. 323-356, 2016.

LiebeS, T.; Blum-KALKA, S. "It takes two to blow the whistle". American Behavioral Scientist, vol. 47, $\mathrm{n}^{\circ} 9$, p. 1.153-1.170, 2004.

LIMA, V. Mídia. Crise política e poder no Brasil. São Paulo: Fundação Perseu Abramo, 2006.

MAIER, J. "The impact of political scandals on political support: an experimental test of two theories". International Political Science, vol. 32, n 3, p. 283-302, 2011.

MAINWARING, S. Introduction: democratic accountability in Latin America. In: MAINWARING, S.; WELNA, C. (eds.). Democratic accountability in Latin America. Oxford: Oxford University Press, 2003.

Matos, C. "Media democratization in Brazil: achievements and future challenges". Critical Sociology, vol. 38, n6, p. 863-876, 2012.

McCombs, M. A teoria da agenda: a mídia e a opinião pública. Petrópolis: Vozes, 2009.

McCOMBS, M.; SHAW, D. "The agenda-setting function of mass media". Public Opinion Quarterly, 
vol.36, n², p. 176-187, 1972.

Michener, G.; PeReirA, C. "A great leap forward for democracy and the rule of Law? Brazil's Mensalão trial". Journal for Latin American Studies, vol. 48, n³, p. 477-507, 2016.

Miguel, L. F; Coutinho, A. A. "A crise e suas fronteiras: oito meses de "Mensalão" nos editoriais dos jornais". Opinião Pública, Campinas, vol. 13, n 1, p. 97-123, 2007.

NEWMAN, N., et al. (eds.). Reuters Institute digital news report 2017. Oxford: Reuters Institute for the Study of Journalism, University of Oxford, 2017.

Pereira, C.; Rennó, L.; Samuels, D. Corruption, campaign finance, and reelection. In: Power, T.; TAYLOR, M. (eds.). Corruption and democracy in Brazil. Indiana: University of Notre Dame Press, p. 80-99, 2011.

PERUzzotTI, E. Media scandals and social accountability. Assessing the role of scandals in Argentina. In: Peruzzotti, E.; SMUlovitz, C. (eds.). Enforcing the rule of law. Social accountability in the new Latin American democracies. Pittsburgh, PA: University of Pittsburgh Press, p. 249-271, 2006.

PORTO, M. The media and political accountability. In: POWER, T.; TAYLOR, M. (eds.). Corruption and democracy in Brazil. Indiana: University of Notre Dame Press, p. 103-126, 2011.

Media power and democratization in Brazil. TV Globo and the dilemmas of political accountability. London: Routledge, 2012.

RenNó, L. Corruption and voting. In: POWER, T.; TAYLOR, M. (eds.). Corruption and democracy in Brazil: the struggle for accountability. Indiana: University of Notre Dame Press, p. 56-69, 2011.

RizotTo, C.; PRUdenCIO, K.; SAMPAio, R. "Tudo normal: a despolitização no enquadramento multimodal da cobertura do impeachment de Dilma Rousseff". Comunicação \& Sociedade, vol. 39, $\mathrm{n}^{\circ}$ 3, p. 111-129, 2017.

RUSSELL, A.; WAISBORD, S. "The snowden revelations and the networked fourth estate". International Journal of Communication, vol. 11, p. 858-878, 2017.

SAAD-FILHO, A. "Mass protests under 'left neoliberalism': Brazil, June-July 2013". Critical Sociology, vol. 39, nº 5, p. 657-669, 2013.

SELIGSON, M. "The impact of corruption on regime legitimacy: a comparative study of four Latin American countries". The Journal of Politics, vol. 64, n 2, p. 408-433, 2002.

SHOEMAKER, P.; VoS, T. Gatekeeping theory. New York: Routledge, 2009.

SNIDERMAN, P.; THERIAULT, S. The structure of political argument and the logic of issue framing. In: SARIS, W. E.; SNIDERMAN, P. M. (eds.). Studies in public opinion: attitudes, nonattitudes, measurement error, and change. Princeton, NJ: Princeton University Press, p. 133-165, 2004.

ThOMPSON, J. Political scandal: power and visibility in the media age. Cambridge: Polity Press, 2000.

TUCHMAN, G. Making news. A study in the construction of reality. New York: The Free Press, 1978.

TUmber, H.; WAISBORD, S. R. "Introduction". American Behavioral Scientist (special issue, vol. II: Political scandals and media across democracies), vol. 47, p. 1.143-1.152, 2004.

UOL ECONOMIA. Universo Online, 2016. Available at:

<http://economia.uol.com.br/cotacoes/cambio/dolar-comercial-estados-unidos/?historico>. Access on: January 5, 2018. 
VALENTE, R. "Em diálogo, Jucá fala em pacto para deter avanço da Lava Jato". Folha de S. Paulo, São Paulo, p. A4, May 23, 2016.

VASTERMAN, P. "Media-hype. Self-reinforcing news waves, journalistic standards and the construction of social problems". European Journal of Communication, vol. 20, n 4, p. 508-530, 2005.

VillaVerde, J. Perigosas pedaladas. São Paulo: Geração, 2016.

WAISBORD, S. Watchdog journalism in South America: news, accountability, and democracy. New York: Columbia University Press, 2000.

WAlgraVe, S.; VLIEgenthart, R. "Why are policy agendas punctuated? Friction and cascading in parliament and mass media in Belgium". Journal of European Public Policy, vol. 17, n 8, p. 1.1471.170, 2010.

WALGRAVE, S., et al. "The nonlinear effect of information on political attention: media storms and U.S. congressional hearings". Political Communication, vol. 34, n 4, p. 548-570, 2017.

WelCh, M.; PRICE, E. A.; YNAKEY, N. "Moral panic over youth violence: wilding and the manufacture of menace in the media". Youth and Society, vol. 34, n³, p. 3-30, 2002.

WiEN, C.; ELMELUND-PRÆSTEKÆR, C. "An anatomy of media hypes: developing a model for the dynamics and structure of intense media coverage of single issues". European Journal of Communications, vol. 24, $\mathrm{n}^{\circ} 2$, p. 183-201, 2009.

WIEWIURA, J.; HENDRICKS, V. "Informational pathologies and interest bubbles: exploring the structural mobilization of knowledge, ignorance, and slack". New Media and Society, article first published online: January 10, 2017, DOI: <https://doi.org/10.1177/1461444816686095>. Access on: January $5,2018$.

WINTERS, M.; WEITZ-SHAPIRO, R. "Lacking information or condoning corruption: when do voters support corrupt politicians?". Journal of Comparative Politics, vol. 45, n 4, p. 418-436, 2013.

\begin{abstract}
Cascading corruption news: explaining the bias of media coverage to Brazil's political scandals

Through a content analysis of 8,800 news items and six months of front pages of three Brazilian newspapers, all dealing with corruption and political transgression, the present article documents the remarkable bias of media coverage toward corruption scandals. Said bias is examined as an informational phenomenon, arising from key systemic and commercial factors of Brazil's news media: an information cascade of news on corruption formed, destabilizing the governing coalition and legitimizing the impeachment process of Dilma Rousseff. As this process gained momentum, questions of accountability were disregarded by the media, with harmful effects for democracy.
\end{abstract}

Keywords: scandals; corruption; impeachment; information cascade; news 


\section{Resumo}

Cascatas de notícias sobre corrupção: explicando viés midiático nos escândalos brasileiros

Fazendo uma análise de conteúdo de seis meses de manchetes em três jornais brasileiros, além de 8.800 notícias sobre corrupção e transgressão política, o artigo estuda o viés da atenção midiática para vários escândalos de corrupção em 2015-2016. Esse viés é examinado como um fenômeno de informação, decorrente de fatores sistêmicos e comerciais no sistema de mídia brasileira: uma cascata de informação sobre corrupção emergiu, desestabilizando a coalizão de governo e legitimando o processo de impeachment de Dilma Rousseff. Com o ímpeto crescente desse processo, questões de accountability foram desconsideradas pela mídia, com efeitos nocivos para a democracia.

Palavras-chave: escândalos; corrupção; cascatas de informações; impeachment; notícias

\section{Resumen}

Noticias cascada de corrupción: explicando parcialidad en la prensa sobre los escándalos brasileños

El artículo estudia la parcialidad de la atención de los medios de comunicación para varios escándalos brasileños de corrupción en 2015-16, en un análisis de contenido de seis meses de páginas delanteras en tres periódicos, además de 8.800 noticias sobre corrupción y transgresión política. Esta parcialidad es examinada como un fenómeno de información, derivado de factores sistémicos y comerciales en el sistema de medios brasileños: una cascada de información sobre corrupción emergió, desestabilizando la coalición de gobierno y legitimando el proceso de impugnación de la presidenta Dilma Rousseff. Con el ímpetu creciente de ese proceso, las cuestiones de accountability no fueron consideradas por los medios de comunicación, con efectos nocivos para la democracia.

Palabras clave: escándalos; corrupción; cascadas de información; impugnación; noticias

\section{Résumé}

Cascades d'information sur la corruption: expliquer la partialité dans la presse lors des scandales du Brésil

En appliquant le concept de "cascades d'information" pour étudier les scandales de corruption, I'opinion publique et les changements politiques, cet article analysera le phénomène de l'information précédant la destitution de la présidente brésilienne Dilma Rousseff. L'article étudiera comment I'information sur la corruption fut largement répandue et construite dans les sphères publiques du Brésil comme par exemple l'élite politique, la presse et les marchés financiers. Dans cette cascade, la valorisation de l'information sur l'affaire Petrobras a été décisive non seulement pour la destitution de la présidente, mais aussi pour la légitimité du processus de mise en accusation. Ce processus a connu un élan grandissant et les questions d'accountability ont été laissées de côté par les médias, ce qui a eu des effets nocifs pour la démocratie.

Mots-clés: scandales; corruption; cascades d'information; destitution; nouvelles

Artigo submetido à publicação em 28 de outubro de 2016. Versão final aprovada em 2 de fevereiro de 2018.

Opinião Pública adopts Creative Commons CC-BY license. $(\mathrm{cc}) \mathrm{EY}$ 